\title{
Demographic Trends in the Manchester-Nashua Metropolitan Area
}

\author{
KENNETH M. JOHNSON, SENIOR DEMOGRAPHER, THE CARSEY INSTITUTE \\ ROBERT MACIESKI, ASSOCIATE PROFESSOR OF HISTORY, \\ UNIVERSITY OF NEW HAMPSHIRE AT MANCHESTER
}

\section{Introduction}

H he Manchester-Nashua metropolitan area has undergone a complex set of population shifts amid growing diversity. This brief documents those changes with recent data. For this research, we divide the Manchester-Nashua metropolitan area into three parts:

- the city of Manchester, with a population of 108,900 in 2007

- the city of Nashua, with a population of 86,800 in 2007

- the balance of Hillsborough County, which we refer to as the suburbs, with a population of 207,000 in 2007

These three regions of the metropolitan area have had distinctly different demographic trends since 1990. Many economic, demographic, and social forces have buffeted the Manchester-Nashua metropolitan area over the past century, and understanding the region's future depends in part on appreciating its past. To that end, the demographic data and analysis provided by Kenneth Johnson are accompanied by sidebars in which Robert Macieski presents the historical perspective on such issues as suburbanization, immigration, diversity, and poverty.

\section{Recent Demographic Trends}

In 2007, the Manchester-Nashua metropolitan area was home to 402,300 residents, or nearly 31 percent of the state's population. It gained 21,000 residents between 2000 and 2007. However, these gains were considerably smaller than those during the 1990s. (For a brief history of population change earlier in the 1900s, see Box A.)

Demographic change stems from a complex interaction of factors. Natural increase (births minus deaths) accounted for 77 percent of the growth in the Manchester-Nashua metropolitan area between 2000 and 2007. In all, births in the metropolitan area exceeded deaths by 16,600 .

Migration accounted for the rest of the population gain.

\section{BOX A: THE TRANSFORMATION OF} MANCHESTER AND NASHUA

n the nineteenth century, industry transformed the towns of Manchester and Nashua from sparse settlements into booming urban centers. Between 1850 and 1900 , Manchester tripled in population to 56,987. Nashua followed suit, also nearly tripling its population, to 23,898 by 1900 . Manchester and Nashua were part of a constellation of New England cotton textile centers that depended on female, immigrant, and child labor. The steady stream of foreign-born and female workers, largely from Europe and Canada, transformed the workforce and the neighborhoods of the two cities. Indeed, at the beginning of the twentieth century, immigrants and their children constituted the majority of the population in both Manchester and Nashua.

However, beginning in 1924 with the National Origins Act, the welcome mat disappeared. The act created a national quota system that effectively closed off the United States to all but a small percentage of immigrant hopefuls from northern and western Europe. The policy was designed to reduce or eliminate the more "foreign" looking and sounding immigrants from eastern and southern Europe, individuals who tended to be among the poorest, considered the least prepared for modern industrial life, of the wrong faiths (Catholic and Jewish), and the most susceptible to union or radical appeal. ${ }^{\mathrm{a}}$

This entire migration gain was due to immigration. Immigration of 8,700 was sufficient to offset the net loss of 3,900 former residents to other areas of the United States. These recent trends contrast sharply with those during the 1990s, when the metropolitan area experienced an inflow of domestic migrants that far exceeded immigration and supplemented substantial natural increase. 


\section{Trends in the Cities and Suburbs}

The cities of Manchester and Nashua grew by 8 percent and 9 percent, respectively, between 1990 and 2000. Suburban gains were even greater at 19 percent (see Figure 1). The gains would slow, however, after 2000. Between 2000 and 2007, Manchester grew by only 1,700 residents ( 2 percent), while Nashua grew by approximately 200 ( 0.3 percent). In contrast, suburban areas grew by nearly 20,000 (11 percent) between 2000 and 2007. The slower growth rates in the cities reflect higher numbers leaving for other destinations than moving in (see Figure 2). All the growth in the cities of Nashua and Manchester between 2000 and 2007 was due to natural increase (the excess of births over deaths). Manchester grew by 4,200 from natural increase (4 percent), and Nashua gained 3,700 (4 percent). Manchester had a net migration loss of 2,500, and Nashua had a net loss of 3,400. Immigration from abroad offset some but not all of this domestic migration loss. ${ }^{1}$ (For a historical look at suburbanization, see Box B.)

FIGURE 1. COMPONENTS OF DEMOGRAPHIC CHANGE IN Hillsborough COUNTY, 1990 to 2000

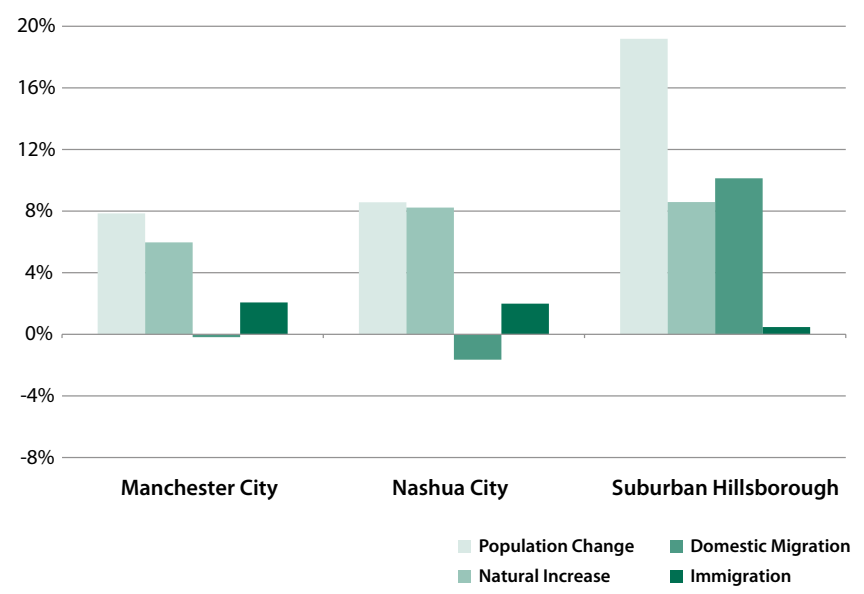

Analysis: K. M. Johnson, Carsey Institute, University of New Hampshire. Source: Census 1990-2000 Intercensal FSCPE.

Note: Domestic migration and immigration estimated for cities and balance using Census 2000 SF3 File.

\section{BOX B: THE MOVE TO THE SUBURBS AND ITS EFFECTS}

hroughout the twentieth century, Hillsborough

County was the state's most populous county.

Growth, however, was uneven across the century. Dur-

ing the first half of the century, growth was relatively

sluggish, in part because of the Great Depression. ${ }^{\mathrm{b}}$ The First World War had also cut the flow of immigrants coming from Europe, and policy following the war constricted immigration further. The Amoskeag Manufacturing Company, Manchester's largest employer and the architect of the city's past, closed its doors on Christmas Eve 1935, leaving in its wake enormous economic and social dislocation and an uncertain future. In 1936, a devastating flood swamped the Merrimack Valley and added to a sense that the city's fortunes were slipping away. Yet while Manchester's share of the county population declined over the twentieth century, Nashua made modest gains. Many New England cities suffered population decline following the Second World War. The relative constancy of Nashua's population growth is one of its impressive characteristics.

As the state's two major cities were slowing (or declining) in growth at mid-century, the suburbs were booming. Yet the same federal housing and highway policies that were subsidizing middle-class suburbanization were also contributing to the "redlining" of many urban neighborhoods, denying capital to places that contained "inharmonious racial and nationality groups," factory smoke or industrial hazards, and multiplefamily dwellings, three characteristics common to New England cities. ${ }^{c}$ Those practices had long-term economic costs, affecting not only those experiencing discrimination but their children as well, who could not draw on or pass along family resources accrued through homeownership as their white contemporaries could.

Economic prosperity in the 1980 s and 1990 s complicated matters further for the poor and for minorities. Rising housing values in the county and gentrification diminished affordable housing. Population density had also been rising in Manchester and Nashua. Population density in Manchester nearly doubled between the beginning of the twentieth century and its end. Nashua's density more than tripled. Whereas city population density was as high as 3,000 persons per square mile, in the suburbs it was roughly 200 persons per square mile by 2000 . 
Figure 2. COMPONENTS OF DEMOGRAPHIC CHANGE IN Hillsborough CoUnty, 2000 TO 2007

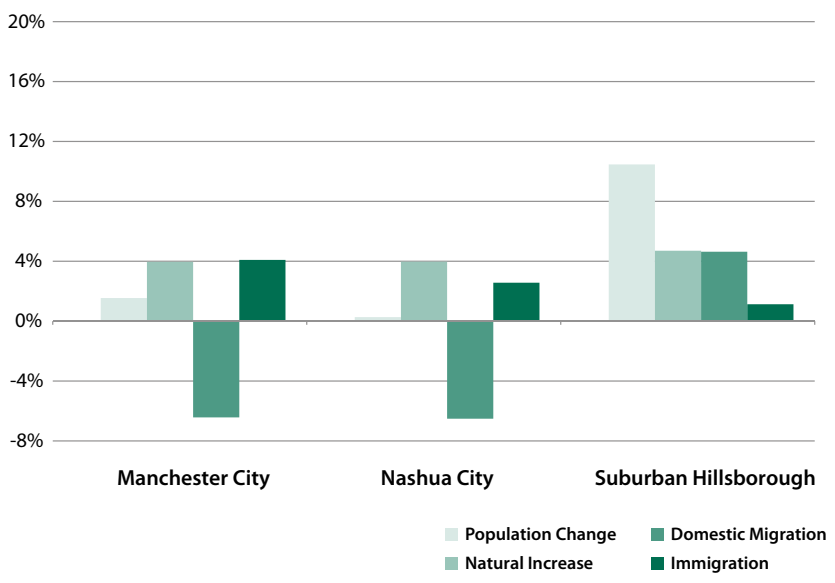

Analysis: K. M. Johnson, Carsey Institute, University of New Hampshire. Source: Census 2008 FSCPE.

Note: Domestic migration and immigration estimated for cities and balance using 2005-2007 American Community Survey data.
In contrast, most of the suburban population gain came from migration (most of it domestic), although there was also significant natural increase. The migration gain of 6 percent was supplemented by an additional 5 percent gain from natural increase. Many suburban migrants are likely to have come from Manchester and Nashua. However, the data do not allow us to estimate the magnitude of this cityto-suburbs migration stream.

Trends during the 1990s foreshadowed those since 2000. Natural increase and domestic migration fueled much of the 1990s suburban population gains, just as they would between 2000 and 2007. Natural increase also accounted for the vast majority of the population gains in Nashua and Manchester during the 1990s, although it was supplemented by modest immigration. Both cities experienced domestic out-migration during the 1990s, just as they would after 2000 , although the magnitude of the decline was far more modest.

\section{BOX C: IMMIGRATION REVISITED}

If the National Origins Act shut the door to many immigrant hopefuls from the 1920s onward, the Immigration and Naturalization Act of 1965 opened it again. The act replaced the quota system with one based on reunification of families and needed skills. With that, immigrants began coming to the United States from Latin America, Africa, and Asia, as well as Europe.

By 2000, immigrants to Manchester and Nashua were no longer solely European or Canadian. Beginning in 1980, the state's foreign-born population began to broaden. New immigrants clustered in neighborhoods in Manchester, as earlier immigrants had. Many of these immigrants are from south-central Asia, Eastern Europe, western Asia, and Africa. While still present, northern Europeans and Canadians no longer monopolize neighborhoods as they once did. Nashua is even more diverse, with neighborhoods populated by Mexicans, South and Central Americans, Asians, Africans, and Pacific Islanders. With immigration, the composition of Hillsborough County shifted. In 1900, the foreign-born composed one-third of the county's population and four of every ten residents in the state. At the other end of the century, in 2000, while the foreignborn made up 7 percent of the county's population, this group represented almost one-half of the state's immigrant population.

In a state known for its racial homogeneity, these changes contributed to a new demographic profile, reflecting New Hampshire's emerging racial diversification. Between 1900 and 2000, Hillsborough County went from 99.7 percent white to 94 percent white. Manchester and Nashua continued to be the principal magnets for immigrants and racial minorities. In 2000, Manchester was 92 percent white, 2 percent African American, 2 percent Asian, and 5 percent Hispanic. Even more diverse, Nashua was 89 percent white, 2 percent black, 4 percent Asian, and 6 percent Hispanic. ${ }^{d}$ The suburbs of Hillsborough, meanwhile, changed little in their share of foreign-born between 1970 and 2000. 


\section{Population Change by Race/ Ethnicity and Immigration}

The Manchester-Nashua metropolitan area is the most diverse part of New Hampshire; nearly 50 percent of all the minority residents of the state reside there. Approximately 11 percent of the metro area's population was minority in 2007. Hispanics, the largest minority, number just over 19,000 (5 percent) and Asians, the second largest minority group, number 12,000 (3 percent). Blacks are 2 percent of the population, with all other groups accounting for the remaining 1 percent. Non-Hispanic whites constitute the majority ( 89 percent) and number nearly 359,800. (Box C provides a historical perspective on immigration in the region.)

There were modest changes in the racial and Hispanic composition of the metropolitan area between 2000 and 2007 (see Figure 3). Although minorities represented only 11 percent of the metropolitan area's population, they produced nearly 70 percent of the population gain between 2000 and 2007. The minority population grew by 15,100 (53 percent) to 43,500 during the period. The white population, in contrast, grew by only 6,300 (2 percent) to 358,800 . Hispanics had the largest numerical gain, but percentage gains among Asians, Hispanics, and African Americans all exceeded 50 percent.

Figure 3. Hillsborough County population CHANGE BY RACE AND HISPANIC ORIGIN, 1990 TO 2007

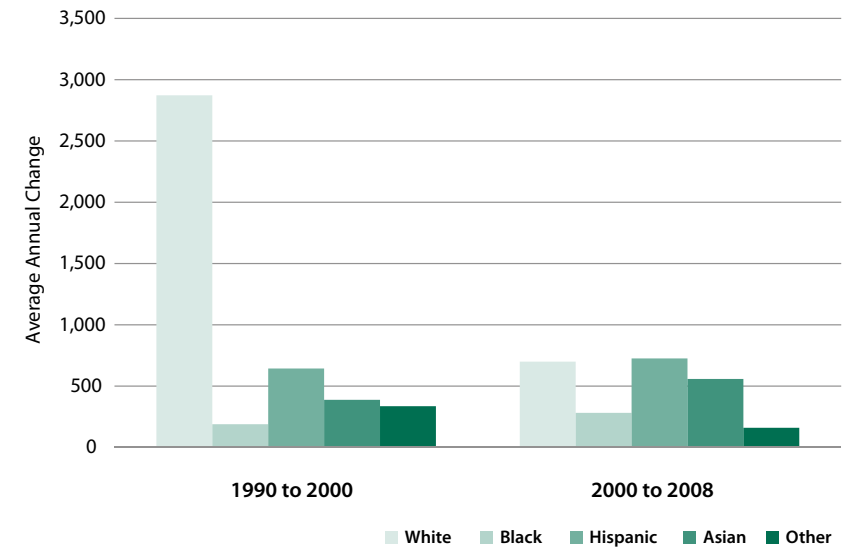

Source: Census 2008 FSCPE; 1990 Intercental FSCPE.
Figure 4. Hillsborough County population

CHANGE BY RACE, 2000 TO 2007

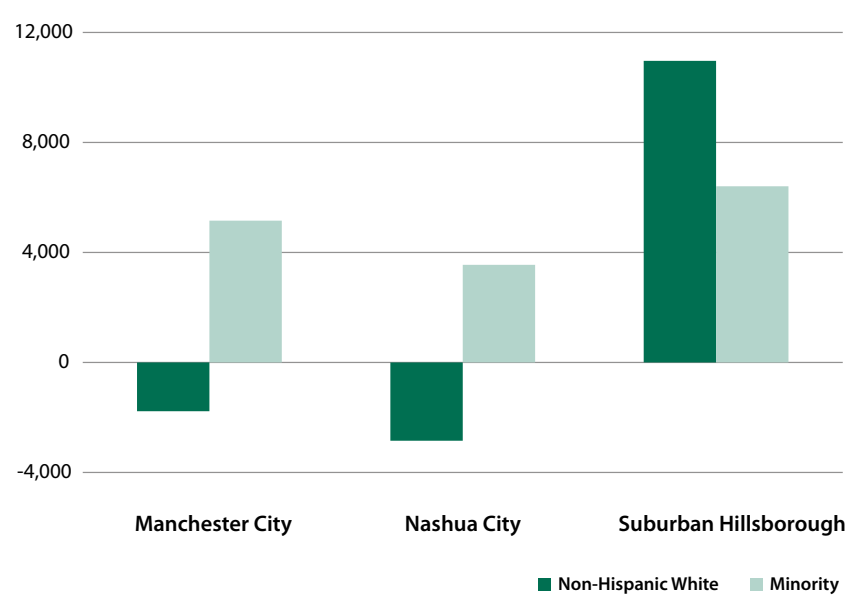

Source: Census 2008 FSCPE; 2005-2007 ACS

Note: 2007 numbers are estimated by applying ACS racial/ethnic proportions to FSCPE estimates.

These minority population gains accounted for all the growth in both Manchester and Nashua (see Figure 4). The minority population grew by 5,200 (32 percent) in Manchester and 3,600 (24 percent) in Nashua. The non-Hispanic white population declined by 2 percent in Manchester and by 4 percent in Nashua.

Trends were quite different in the suburbs. Most of the suburban population gain was fueled by non-Hispanic white growth of 11,000 ( 6 percent). The minority population in the suburbs had a greater percentage gain (56 percent), but it was smaller in absolute size $(6,400)$. Minorities still constituted a small share (6 percent) of the suburban population as of 2007.

Immigrants are an important source of this diversity. The Manchester-Nashua area has long been a point of entry for immigrants. Contemporary immigration levels certainly do not compare to historical levels, but immigrants remain an important source of growth for the region. An estimated 8,700 immigrants moved to the metropolitan area between 2000 and 2007. They represent more than one-third of the area's population gain during the period.

Most of these immigrants settled in the cities of Nashua and Manchester, but a modest number settled in the suburbs as well. Approximately 9 percent of the metropolitan area's population is foreign-born, a far cry from the near majority at the turn of the last century, but certainly enough to underscore the continuing importance of immigrants to the region's future. (For more about immigration in the Manchester-Nashua metropolitan area, see Box D.) 


\section{BOX D: IMMIGRATION AND THE FOREIGN-BORN}

M any factors go into the decision to emigrate. Conditions in one's native lands, political unrest, economic opportunities, religious freedoms, and familial needs all influence who arrives, where they settle, and what they expect to find. Immigration is rarely an arbitrary decision. Those who migrate leave others behind; some follow later, and some do not. In the process, immigrants forge intense and complex bonds between their new homes and their old, mixing interests and loyalties that span the two places.

These loyalties and familial networks mean that immigrants do not just land randomly in the cities of Manchester or Nashua. They tend to cluster in certain neighborhoods. Some groups cluster more than others, but what is consistent is that particular neighborhoods in both Nashua and Manchester continue to serve as home to newly arrived immigrants. The immigrant group may change, but the neighborhood remains a beacon.

In Manchester in 1910, for instance, French Canadians composed the largest immigrant group by far, with strong presence in wards 3, 4, and 9. Greeks, Russians, and Turks, meanwhile, concentrated in wards 4 and 5 , along with Irish immigrants. Germans lived largely in the west side's ward 9, and Austrians were in wards 3 and 4.

A decade later, the number of Greek immigrants had grown considerably, clustering largely in ward 5, and Polish communities were emerging in wards 5, 8 , and 9. The presence of Irish and Russian immigrants had faded, as both nations fought civil wars and revolutions. German immigrants continued to move into the west side, while the number of Austrian immigrants diminished considerably, replaced by a small clustering of Belgian immigrants in the eleventh ward. In both 1910 and 1920, the Census showed the same areas in Manchester accounted for the largest concentrations of the foreign-born, despite residents shifting places of birth. ${ }^{e}$ By century's end, these neighborhoods would still be home to immigrants, although they were now largely from a wider range of countries beyond Europe and Canada.

\section{Migration's Effect on the Age of a Population}

New Hampshire policy makers are properly concerned about the loss of young people from the state. However, crafting appropriate solutions depends on a clear understanding of the underlying forces driving the changes. Previous Carsey Institute research stated that the diminished number of young adults is not the effect of "brain drain" but instead the result of trends that began 40 years ago with the baby boom. ${ }^{2}$ Given the importance of migration to the region's future, what do current migration trends suggest? Recent Census estimates indicate the inflow of migrants to New Hampshire as a whole has slowed dramatically in the last several years. In fact, it is possible that the state is now experiencing net out-migration for the first time in nearly 20 years. Whether this represents a new trend or a short-term fluctuation stemming from an economic recession and the housing market decline remains to be seen. Without the detailed data available in the decennial census, we can only estimate age-specific effects of migration. However, the estimates for 2000 through 2005 suggest a continued inflow to the state of new residents aged 30 to 49 and their children. There is also evidence of increased net gains among those 50 to 69 , in part because the baby boomers are now entering this age group. New Hampshire also appears to have received a net influx of 20 - to 29 year olds during the first half of the decade. This differs from the 1990s, when modest numbers in this age group left the state.

Because Hillsborough County contains nearly a third of the state's population, it is important to understand how recent migration patterns have influenced the age structure of the area. Historically, migration played an important role in reshaping the population in the Manchester-Nashua metropolitan area. Manchester's transformation from a fading mill town to a diversified regional center over the past several decades has attracted migrants, particularly in the 1990s, as has the proximity of the Boston metropolitan area. Recently, domestic migration losses from the county have dramatically slowed population growth. ${ }^{3}$

Examining net migration by age provides additional insights into the demographic change underway in the metropolitan area. Manchester-Nashua gained migrants in most age groups between 1990 and 2000 (see Figure 5). Numerical gains were greatest among those in their 30 s and among children. The county retained most of its young adults, but it did lose some retirement-age population. Because adults in their 30 s are in the midst of rearing families, it is not surprising that gains in the child population accompanied the gains of those in their 30s. These findings are consistent with those for the state as a whole. ${ }^{4}$ Such an inflow has significant implications, because family households bring considerable social and financial capital, and the large number of children will put additional demands on local schools. 
Figure 5. Age-SPECIFIC NET MIGRATION IN

Hillsborough CoUnty, 1990 TO 2000

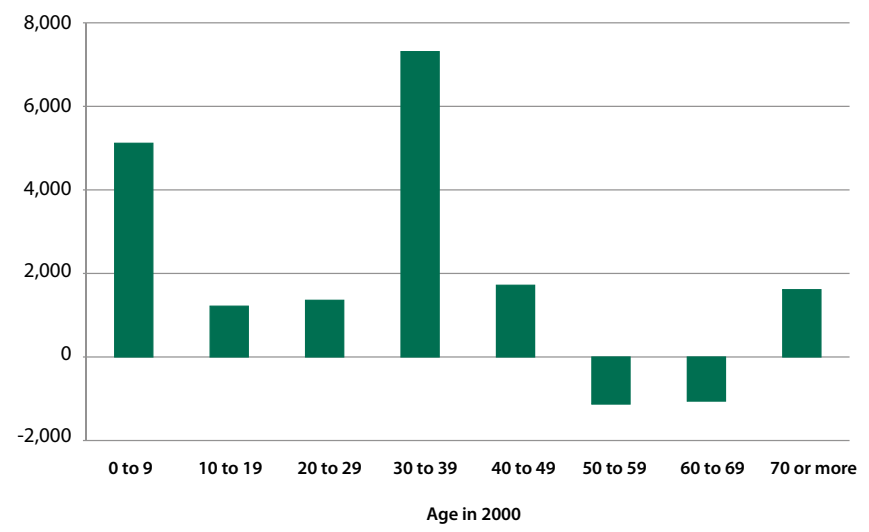

Source: Johnson et al. 2005. "Temporal and Spatial Variation in Age-Specific Net Migration in the United States."

Demography 42:791-812

Between 1990 and 2000, the number of people aged 20 to 29 in the metropolitan area declined by 24 percent. Yet, Figure 5 suggests a net inflow to the metropolitan area of 20 - to 29 year olds between 1990 and 2000. If the Manchester-Nashua area did not experience young adult out-migration during the 1990s, then how could the young adult population decline during the period? The explanation is demographic. The decline occurred because relatively few children were born during the 1970s; baby boomers delayed childbearing and had fewer children. As a result, in 1990, there were more than 59,000 20- to 29 year olds (those born prior to 1970) in Hillsborough County but only 44,500 10to 19 year olds (those born after 1970). As this small cohort reached their 20s during the 1990s, the number of young adults in the area declined sharply. In contrast, 54,000 children were aged 10 to 19 in 2000 (those born to baby boomers from the 1980s on). As a result, the number of 20to 29 year olds grew slightly by 2007 . However, it appears that the metropolitan area did lose a modest number of 20 - to 29 year olds in the last year or two. Whether this is a short-term loss related to the current economic problems or a shift in migration patterns remains to be seen.

The pattern of migration by age differs within the metropolitan area, reflecting the different life cycle stages of each population. In the suburbs, a larger proportion of the population is in their 30 s and 40 s, which are prime family years. In contrast, Manchester and Nashua have a larger proportion of their population in their 20s. As a result, half of all households in suburban Hillsborough County include children, compared with 27 and 30 percent, respectively, in Manchester and Nashua (see Figure 6).
Figure 6. Hillsborough County Age Structure, 2000

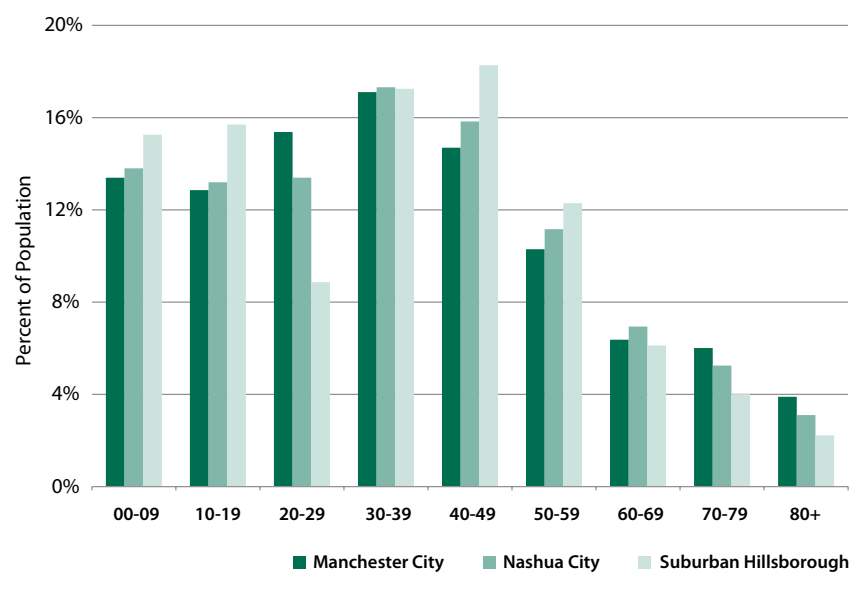

Source: Census 2000 Summary File (SF1).

The age structures illustrate another major policy concern. The number of older adults will increase rapidly in the near future, because current residents will age in place. There are currently 34,000 individuals aged 60 to 69 in the Manchester-Nashua metropolitan area. In contrast, there are 57,000 people aged 50 to 59 . Although mortality and out-migration will modestly reduce this cohort, the vast majority will still reside in the metropolitan area in ten years. In addition, the number of those currently between the ages of 40 and 49 is some 25 percent larger than the current 50- to 59-year-old cohort.

In sum, recent age-specific migration trends for the Manchester-Nashua metropolitan area contain no evidence of a young adult brain drain. They do suggest the region is continuing to gain households in their 30 s and 40 s together with their children. We next turn our attention to the implications of such migration for income and poverty. 
Migration and Income Flows to the Manchester-Nashua Metropolitan Area

Using Internal Revenue Service data to examine the flow of migrants and income to and from the Manchester-Nashua metropolitan area provides further insights into how migration is reshaping the region. ${ }^{5}$ Such data reveal that 2,000 more people moved out of the Manchester-Nashua metropolitan area than moved in from 2000 to 2007 . The sheer volume of migration that produced this net change is stunning. Some 127,000 people moved into the metropolitan area and 129,000 left. So, the migration of nearly 256,000 people only produced the small net change of $2,000 .^{6}$

The Manchester-Nashua metropolitan area gained a significant number of migrants from exchanges with the Boston metropolitan area. ${ }^{7}$ Over 37,200 people moved from Boston to the Manchester-Nashua metropolitan area, while only 17,800 moved in the opposite direction, resulting in a net migration gain of 19,400 (see Figure 7). The area also gained modestly from migration exchanges with the rest of New England and the Mid-Atlantic states. In contrast, there was a significant net loss of migrants to other areas of New Hampshire as well as to the South and, in smaller amounts, to the West and Midwest.

Figure 7. Migration to AND From Hillsborough

COUNTY, 2000 TO 2007

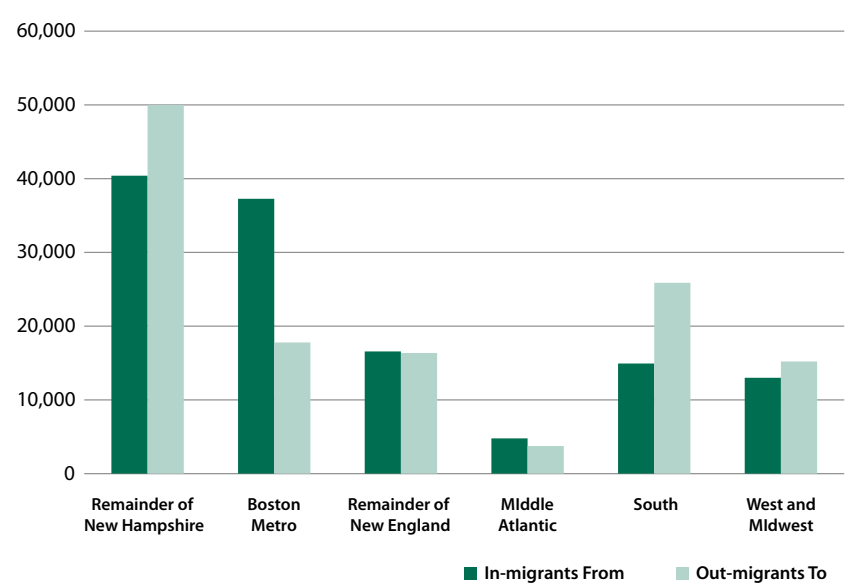

Source: IRS County Data Aggregate Change, 2000-2007.
Despite the net loss in population, the metropolitan area experienced a net income gain of $\$ 102$ million from these migration exchanges. (Households leaving the metropolitan area had an aggregate income of roughly $\$ 3.64$ billion, whereas those moving in earned $\$ 3.74$ billion.) ${ }^{8}$ One reason for this gain is tied to the growth in family households, which tend to have higher incomes than other households.

\section{BOX E: POVERTY}

Doverty has never been a stranger to Hillsborough County. It persisted throughout the century, ending with disturbingly high poverty rates amid affluence. Early in the century, the daily struggle for economic survival was commonplace. Many workers, particularly women, immigrants, and children, could expect low wages, scheduled layoffs, and no social welfare support other than family, kin, and the kindness of strangers. Families responded with creative strategies, sending family members into different industries, like shoe and textile factories, to hedge against downturns. Women brought in additional income by taking in boarders, laundry, or sewing. Family members saved on expenses by sharing childrearing responsibilities, growing gardens, tending a goat or chicken, hunting, fishing, or scavenging. They joined unions, mutual benefit or sickness and death societies, and sought solace and support within the walls of their synagogues and churches. The steady influx of immigrant labor kept wages low, as did the widespread presence of women in the workforce, married and unmarried, and the additional competitive drains of child labor.

These conditions combined to give Manchester the third-highest infant mortality rate in the country. A 1917 study on infant mortality by the newly created Children's Bureau stated that high infant mortality was the product of "a large foreign population and a considerable proportion of industrially employed women." The rate was far higher for foreign-born women. There were also wide discrepancies between immigrant groups. French Canadian women lost the most babies, followed by Polish mothers. English, Irish, and Scottish mothers in the study had the lowest rates, far below native-born women. The study concluded that the high level of infant mortality was the direct result of low family incomes. ${ }^{f}$ These conditions supported arguments for Progressive-era reforms that expanded the role of government to insure public health, protect the environment, establish financial order, and provide for social and civic welfare. 
Figure 8. MigRANT INCOME FLOWS TO AND FROM Hillsborough County

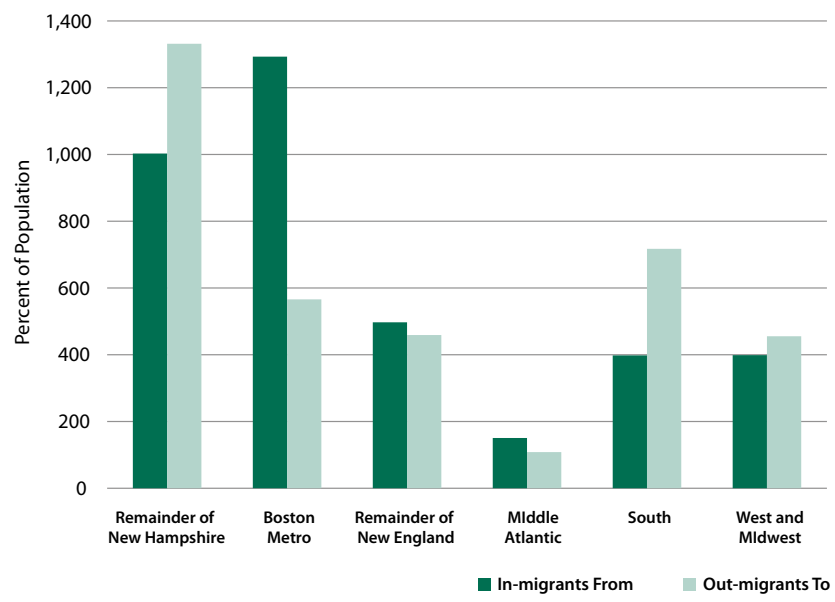

Source: IRS County Data Aggregate Change, 2000-2007.
The largest gain (\$727 million) came from the influx from Boston but also from exchanges with the Mid-Atlantic states. In contrast, the metropolitan area lost income in migration exchanges with the rest of New Hampshire as well as with the South, West, and Midwest. The incomes of those leaving for other areas of the state exceeded that of new residents by $\$ 329$ million (Figure 8 ). The net loss to the South, which likely includes some affluent retirement-age migrants, was also substantial at \$319 million, and the loss to the Midwest and West was more modest at $\$ 57$ million.

\section{BOX F: THE DEPRESSION YEARS AND BEYOND}

rente he Depression years were very difficult, especially in Manchester, where the "calamitous" closing of the city's largest employer, Amoskeag Manufacturing Company, in 1935 devastated the already depressed city. Hardship was widespread. Local, state, and federal assistance could barely keep pace with need. Economic conditions deteriorated to such a point that in 1936 a Works Progress Administration (WPA) report noted that one-third of Manchester's families received general assistance or WPA work. ${ }^{9}$ The New Deal policies of unemployment insurance, worker's compensation, and Social Security dramatically altered both the composition and character of poverty by moderating the severity of life cycles and life's misfortunes. Nationally, widespread unionization raised wages, improved working conditions, brought benefits, and gave powerful political voice to the working class for the first time. Following the war, the GI Bill helped elevate this generation further, through public commitment to education, housing, and small business creation and assistance.

Military spending during World War II helped revive the economy, and continued spending from the cold war to the present provided a guaranteed market that serves as economic ballast. Pent-up consumer demand after the war, fueled by the emerging baby boom, helped shift the economy to consumer based, launching what many view as a "golden age" of prosperity. The emergence and expansion of the middle class lifted the lives of many from the precariousness of poverty.

The loss of the Amoskeag Manufacturing Company was symptomatic of the slow, gradual departure of industry from the region. In the late nineteenth century, under intense competitive pressures, many manufacturers began to move their operations to the South, where deprivation was greater and cheap and nonunionized labor abundant. This increased the pressures on remaining manufacturers to keep their costs low and ultimately contributed to a lowwage economy. Ironically, the rising standard of living in Hillsborough County acted in some ways as an incentive for industries to leave. Those same pressures continue today in what we call globalization.

Prosperity was never universal. As Hillsborough County residents were buying homes in the suburbs and enjoying the prosperity of postwar America, the decline of manufacturing was dislocating others. The service sector is diverse, and incomes can vary from quite high for some to minimal for many. Profound transformations in gender, race, and family relations in the second half of the century added to the complexity.

How have these changes affected the demography of poverty in Hillsborough County? At first glance, poverty seems unexpectedly high in $\mathbf{2 0 0 0}$ given the widespread prosperity of the 1980s and 1990s. In Manchester, 11 percent of the population earned below the poverty level of $\$ \mathbf{8 , 5 0 1}$ for an individual, and 8 percent of families lived below the poverty level, set at $\$ \mathbf{1 7 , 0 2 9}$, for a family of four. In 2000 , Nashua had a lower poverty rate, although still significant, with 5 percent of families and 7 percent of individuals living in poverty. These levels are lower than the national average in 1999 of 12 percent for individuals. ${ }^{h}$ 


\section{Income and Poverty in the Manchester-Nashua Metropolitan Area}

Migration produces a net income gain to the metropolitan area, but significant income disparities remain in the region. With a median family income of $\$ 79,200$, Hillsborough County is above the state average of $\$ 73,200$. But incomes vary widely within the county. The highest incomes are in families in suburban Hillsborough County, at $\$ 90,000$ (see Figure 9). The lowest are among families in Manchester proper, at $\$ 65,000$. Incomes in Nashua fall in between, at $\$ 76,000$. Incomes have consistently been higher in suburban Hillsborough County since at least 1990.

Figure 9. MEDIAN FAMILY INCOME IN

Hillsborough County, 1989 TO 2007

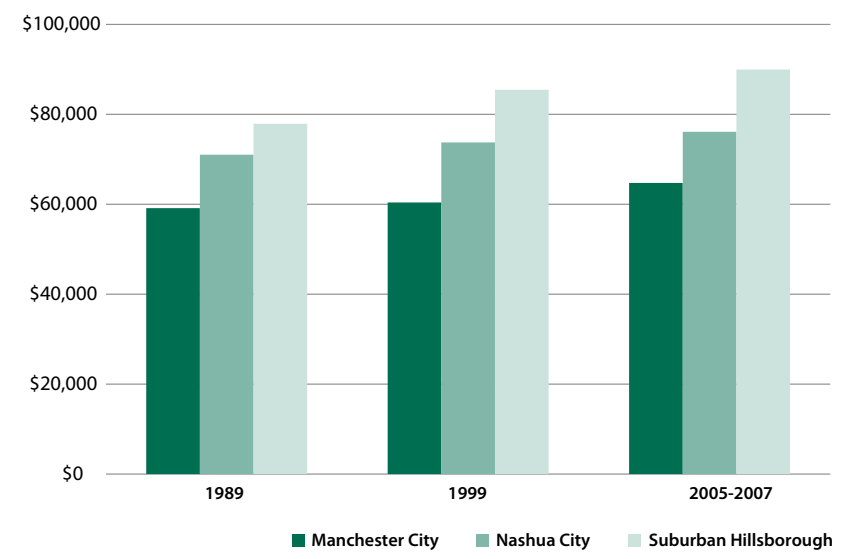

Source: Census 1990 Summary Tape File 3; Census 2000 Summary File 3; 2005 2007 American Community Surveys.

Note: Dollar amounts adjusted to 2007 dollars using CPI-U-RU.

New Hampshire has long been recognized as a state with low poverty levels, particularly among its children. The percentage of children in poverty in 2007 in New Hampshire (10 percent) was the lowest in the nation. Thus, it is surprising to find extremely high child poverty rates in some parts of the Manchester-Nashua metropolitan area. In the city of Manchester, 25 percent of all children lived below the poverty line in 2007. In contrast, in Nashua, only 8 percent of children are in poverty, and in suburban areas it is even lower, at 5 percent (see Figure 10). These disparities in poverty levels across the metropolitan area have a long history. (See Boxes $\mathrm{E}$ and $\mathrm{F}$ for historical background on income and poverty in the region.)
Figure 10. Children in POVERTy in Hillsborough COUNTY, 1989 TO 2007

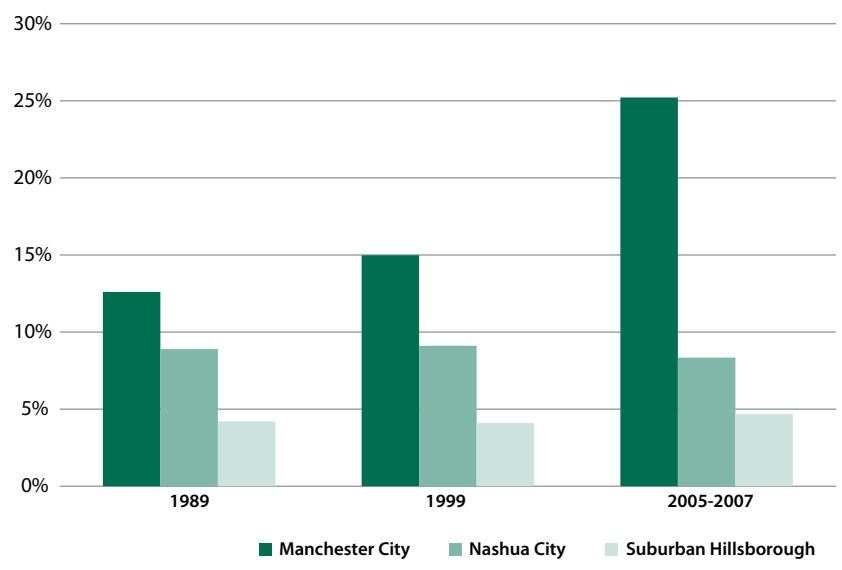

Sources: 2005-2007 American Surveys; 2000 Census Summary File 3: 1990 Census Summary Tape File.

Explanations for such disparities are beyond the scope of this report, but differences in family structure are one factor. Both nationally and in New Hampshire, the lowest rates of child poverty are in married-couple households. In the Manchester-Nashua metropolitan area, only 2 percent of married couples with children live in poverty. Although the share of married-couple families in poverty is higher (6 percent) in Manchester than in the metro areas as a whole, this difference does not account for the strikingly higher child poverty levels there. What does account for the disparity is the higher shares of married parents in the suburbs and Nashua. In suburban Hillsborough County, 81 percent of families with children are married-couple households. In Nashua, 73 percent are. In Manchester, only 58 percent of families with children are married couples. Thus, the higher child poverty rates in Manchester are, in large part, a result of the larger proportion of single-parent families in the city. 


\section{Conclusion}

With 402,000 residents, the Manchester-Nashua metropolitan areas represented nearly a third of the population of New Hampshire in 2007. After growing faster than the state average in the 1990s, growth in the Manchester-Nashua metropolitan area slowed after 2000. Within the metropolitan area, demographic trends in the cities of Manchester and Nashua differ sharply from those in the suburban areas. The two cities registered minimal population gains between 2000 and 2007. In contrast, the suburbs grew significantly. The differential growth rates in the city and suburban areas of the metropolitan area reflect different patterns of demographic change. Growth in the cities of Nashua and Manchester was due to natural increase (the excess of births over deaths). More people migrated out of the cities than moved in. In contrast, most of the suburban population gain came from migration, although this was supplemented by natural increase.

The metropolitan area is also becoming more diverse because minority populations are growing at a much more rapid rate than the non-Hispanic white majority. The area is already the most racially diverse in the state, with nearly 11 percent of the population belonging to a minority group. Between 2000 and 2007, diversity increased in the area because minority populations grew, while the non-Hispanic white population declined in both Manchester and Nashua. Immigration is also contributing to the increasing diversity of the region.

Demographic change has implications that go beyond the movement of people. As the population changes, income and poverty levels change. Incomes in the ManchesterNashua area are quite high, but there is considerable variation within the region. Incomes are highest in the suburbs and lowest in the city of Manchester. The state of New Hampshire has the lowest rate of child poverty in the United States, yet 25 percent of the children in the city of Manchester are in families with incomes below the poverty level. In contrast, child poverty levels in suburban areas and in Nashua are considerably lower. The current demographic situation in the Manchester-Nashua metropolitan area has been shaped by historical, social, economic, and demographic forces. This brief provides both a detailed portrait of the contemporary demographic trends in the region and insights into the historical factors that have shaped these trends to inform planning for the region's future.

\section{About this Brief}

This research is part of a partnership between the Carsey Institute and the University of New Hampshire at Manchester to develop an applied research agenda to foster increased understanding of trends in small cities. Research projects will address challenges facing today's small cities, particularly those involving vulnerable children, youth, and families, as well as sustainable community development.

\section{Data}

Demographic data for this study come from the FederalState Cooperative Population Estimates Series, the American Community Survey, and the 1990 and 2000 decennial census, all of which are products of the U.S. Census Bureau. Additional data are from the county-to-county migration series of the Internal Revenue Service. The migration estimates derived from the IRS data should be interpreted with caution. Although IRS data is comprehensive, those who do not file returns or are filing their first return are excluded from the migration analysis. Also, much of the data used here for the post-2000 period is based on Census Bureau estimates. Although such estimates have proved reliable in the past, they are not as accurate as data derived from the decennial census. The impact of these factors is unknown, but the overall trends suggested in this report are likely to reflect the actual situation in the Manchester-Nashua metropolitan area. For more detailed analysis of recent demographic trends in New Hampshire and a detailed discussion of methods, see the Carsey Institute report The Changing Faces of New Hampshire: Recent Demographic Trends in the Granite State available at http://www.carseyinstitute.unh.edu/ publications/Report_NH_Demographics.pdf 


\section{Endnotes}

1 The Census Bureau does not provide subcounty immigration data. We have estimated immigration for Manchester, Nashua, and the suburban area by using Census 2000 SF3 data and allocating the post-2000 immigration to the three regions in the same proportions as was reported in Census 2000.

${ }^{2}$ Kenneth M. Johnson, The Changing Faces of New Hampshire: Recent Demographic Trends in the Granite State, A Carsey Report on New England (Durham, NH: Carsey Institute, University of New Hampshire).

${ }^{3}$ Because the data and computational demands required to produce such detailed age-specific migration estimates are substantial, they can only be produced with data from the decennial census.

${ }^{4}$ Johnson, The Changing Faces of New Hampshire.

${ }^{5}$ IRS data do not cover the entire population, but the coverage is quite comprehensive. Therefore, conclusions drawn from analysis of the IRS migration data are likely to be indicative of overall migration and income streams to and from the region. IRS data do not cover immigrants, so the data presented are for internal migrants within the United States and U.S. residents returning from abroad.

${ }^{6}$ Some individuals who moved into the area between 2000 and 2007 subsequently left the region. Others who left the region during the period may have returned before it ended. Thus, the reported figure more accurately reflects the number of moves rather than the number of people moving.

${ }^{7}$ For purposes of examining migration here, the Boston Metropolitan area is defined as the five counties included in the Boston-Cambridge-Quincy Metropolitan Statistical Area that are in Massachusetts.

8 The income gain resulting from migration only includes the income of the household in the year they enter the state. That is, for a household moving to New Hampshire in 2002, only the income earned in that tax year is included in our calculations. The additional income they earn in 2003, 2004, and 2005 is not included. Thus, our estimate of the income gain garnered by migration is conservative.

\section{Historical Perspective Boxes}

a Prolonged strikes during the war and in the early 1920s helped generate local variants of this sentiment. Both Manchester and Nashua were prominent targets of the Palmer raids in 1920, when government agents and vigilante enthusiasts rounded up hundreds of immigrants and held them incommunicado as suspected "Reds."

b This pattern reflects the demographic patterns characteristic in the Northeast and Midwest during this period. Frank Hobbs and Nicole Stoops, Demographic Trends in the 20th Century: Census 2000 Special Reports (Washington, DC: U.S. Census Bureau, November 2002), 19-20.

c See Kenneth T. Jackson, Crabgrass Frontiers: The Suburbanization of America (New York: Oxford University Press, 1987).

${ }^{d}$ U.S. Census, DP-1 Profile of General Demographic Characteristics 2000, Census 2000 Summary File 1 (SF 1) 100-Data. The figures used for the Hispanic population are for Hispanics of all races.

e Manchester was divided into ten wards in 1910 and thirteen in 1920, making direct comparisons difficult.

f Children's Bureau, Department of Labor, Infant Mortality in Manchester, NH (Washington, DC: Department of Labor, 1917), 56.

g Daniel Creamer and Charles W. Coulter, Labor and the ShutDown of the Amoskeag Textile Mills, WPA, National Research Project, Report No. L-5 (Philadelphia: National Research Project, November 1939).

h Bishaw Alemayehu and Jack Iceland, Poverty 1999: A Census 2000 Brief (Washington, DC: U.S. Census Bureau, May 2003). 


\section{A C K N OW L E D G M E N T S}

The authors gratefully acknowledge research assistance provided by Allison Churilla and Skye MacKay of the Carsey Institute, University of New Hampshire.

\section{ABOUT THE AUTHORS}

Kenneth M. Johnson is the senior demographer at the Carsey Institute and a professor of sociology at the University of New Hampshire.

Robert Macieski is an associate professor of history at the University of New Hampshire at Manchester. $\triangle$ UNIVERSITY

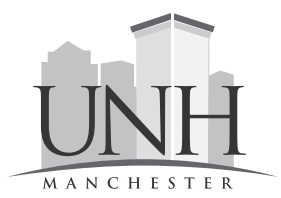

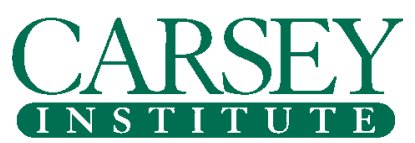

Building knowledge for families and communities

The Carsey Institute conducts policy research on vulnerable children, youth, and families and on sustainable community development. We give policy makers and practitioners timely, independent resources to effect change in their communities.

This research was supported by Dean Kristin Woolever at the University of New Hampshire at Manchester, by the New Hampshire Charitable Foundation, and by the Carsey Institute endowment.

Huddleston Hall

73 Main Street

Durham, NH 03824

(603) $862-2821$ 